\begin{tabular}{|l|l|}
\hline $\begin{array}{l}\text { 2. To: (Receiving Organization) } \\
\text { Distribution }\end{array}$ & $\begin{array}{l}\text { 3. From: (Originating Organization) } \\
\text { SNF Characterization Project } \\
\text { 2F700 }\end{array}$ \\
\hline 5. Proj./Prog./Dept./Div.: & $\begin{array}{l}\text { 6. Design Authority/ Design Agent/Cog. } \\
\text { Engr.: }\end{array}$ \\
Spent Nuclear Fuel Project & B.J. Makenas
\end{tabular}

Spent Nuclear Fuel Project

8. Originator Renarks:

For approval and release.

11. Receiver Remarks: 11A. Design Baseline Document? [] Yes [X] No
3. From: (Originating organization) SNF Characterization Project/ 2F700

6. Design Authority/ Design Agent/Cog. Engr.:

B.J. Makenas

4. Related EDT No.:

$\mathrm{N} / \mathrm{A}$

7. Purchase Order No.:

$\mathrm{N} / \mathrm{A}$

9. Equip./Component No.:

$\mathrm{N} / \mathrm{A}$

10. System/Bldg./Facility:

$\mathrm{N} / \mathrm{A}$

12. Major Assm. Dwg. No.:

$N / A$

13. Permit/Permit Application No.: N/A

14. Required Response Date: $N / A$

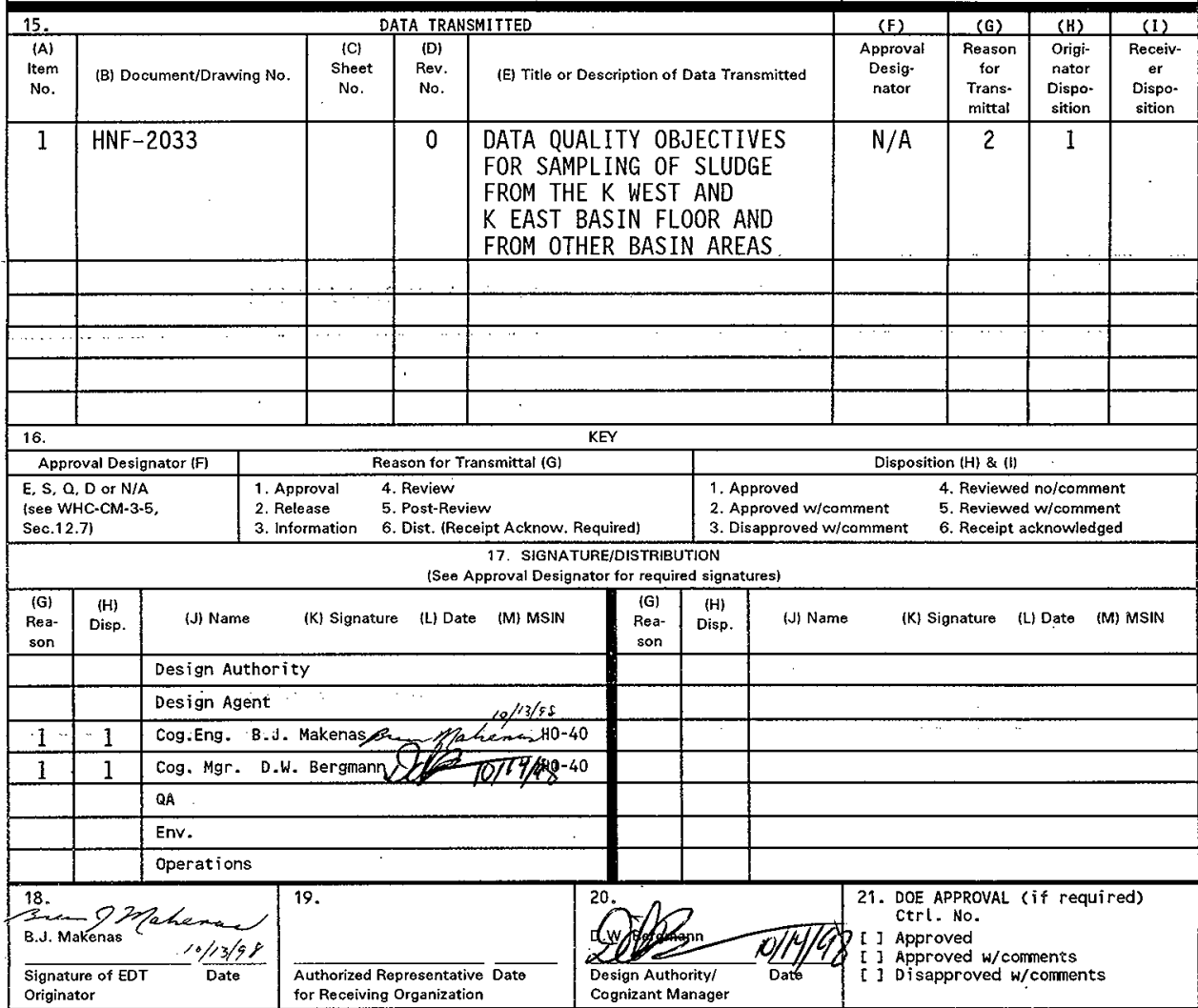




\section{DATA QUALITY OBJECTIVES FOR SAMPLING OF SLUDGE FROM THE $K$ WEST AND K EAST BASIN FLOOR AND FROM OTHER BASIN AREAS}

B. J. Makenas

Duke Engineering \& Services Hanford, Inc., Richland, WA 99352

U.S. Department of Energy Contract DE-AC06-96RL13200

EDT/ECN: 620818

Org Code: 2F700

B\&R Code: EW7040000
UC: UC 2070

Charge Code: 105358

Total Pages: 38 a $10-21-98$

Key Words: K Basin, Sludge, Data Quality Objectives

Abstract: This document addresses the characterization strategy for those types of sludge not previously characterized or discussed in previous DQO documents. It seeks to ascertain those characteristics of uncharacterized sludge which are unique with respect to the properties already determined for canister and $K$ East Basin floor sludge. Also recent decisions have resulted in the need for treatment of the sludge prior to its currentiy identified disposal path to the Hanford waste tanks. This has resulted in a need for process development testing for the treatment system development.

TRADEMARK DISCLAIMER. Reference herein to any specific comercial product, process, or service by trade name, trademark, manufacturer, or otherwise, does not necessarily constitute or imply its endorsement, recomendation, or favoring by the United States Government or any agency thereof or its contractors or subcontractors.

Printed in the United States of Anerica. To obtain copies of this document, contact: Document Control Services, P.0. Box 950, Mailstop H6-08, Richland WA 99352, Phone (509) 372-2420; Fax (509) 376-4989.
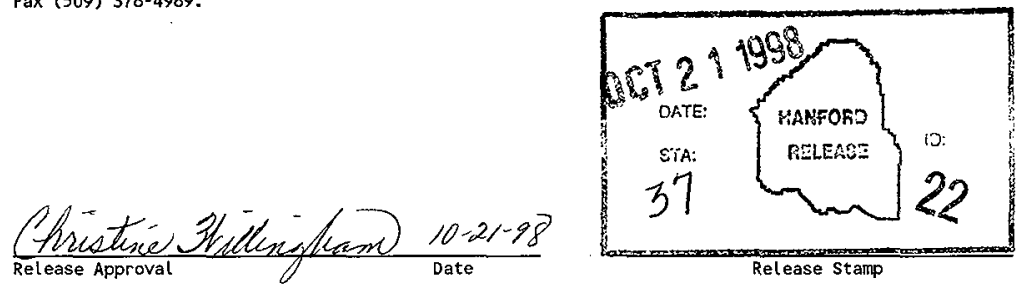

\section{Approved for Public Release}


HNF-2033, Rev. 0

DATA QUALITY OBJECTIVES FOR SAMPLING OF SLUDGE FROM THE K WEST AND $K$ EAST BASIN FLOOR AND FROM OTHER BASIN AREAS

B. J. Makenas and R. B. Baker

Duke Engineering \& Services Hanford, Inc.

October 1998 
Document Title: DATA QUALITY OBJECTIVES FOR SAMPLING OF SLUDGE FROM THE $K$ WEST AND $K$ EAST BASIN FLOOR AND FROM OTHER BASIN AREAS

Prepared by:

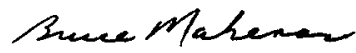

B. J. Makenas

SNF Characterization Project

RB Bahen

R. B. Baker

SNF Characterization Project

Reviewed by:

Approved by:

Approved by:

Approved by:

S G num

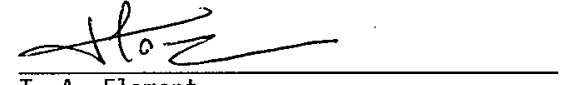

T. A. Flament

Numatec Hanford

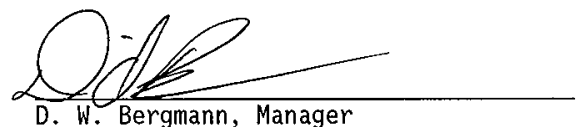

SNF Characterization Project

B.W. Smith

SNFP Quality Assurance

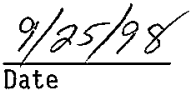

$\frac{10 / 8 / 98}{\text { Date }}$

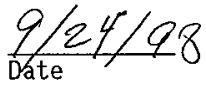

$9 / 21 / 58$

Date

J. Shuen

U.S. Department of Energy

$\frac{9 / 24 / 98}{\text { Date }}$ 
HNF-2033, Rev. 0

\section{EXECUTIVE SUMMARY}

This document addresses the characterization strategy for those types of sludge not previously characterized or discussed in previous DQO documents. It seeks to ascertain those characteristics of uncharacterized sludge which are unique with respect to the properties already determined for canister and $K$ East Basin floor sludge. Also recent decisions have resulted in the need for treatment of the sludge prior to its currentiy identified disposal path to the Hanford waste tanks. This has resulted in a need for process development testing for the treatment system development.

There are three principal problems related to sludge to be addressed by the current DQO. First, the proposed sludge treatment process must confront all of the various sludges in the two basins. It is meant to safely alter particle size and eliminate pyrophoric constituents, polychlorinated biphenyls (PCBs), and nonradiolytic gas generation. Various dilution, chemical addition, and precipitation steps are envisioned. It should be ascertained whether any of the sludge types contain constituents incompatible with currently envisioned processes. This should be accomplished before (1) the treatment process/equipment final design is completed and (2) before the sludges are commingled because it is not currently planned to have a separate processing run (or conditions) for al1 identified types of sludge.

Secondly, the effectiveness of sludge treatment is being demonstrated in various laboratory-scale and/or pilot-scale tests prior to treatment being initiated for the bulk of the basin sludge. Currently there is not enough sludge in the laboratories (left over from previous specific characterization campaigns) to perform the tests that are proposed. 
Thirdly, the knowledge of sludge chemical composition, radiological properties, and physical properties is incomplete. Although several types of sludge have been sampled and analyzed, areas of the basin remain where no analyses have been performed. It may be necessary to have a working knowledge of sludge composition to obtain approvals and permits to ship and handle sludge. Although the types of sludge remaining to be characterized are assumed to be less aggressive and less voluminous than those atready investigated, it is still prudent to test this assumption and ascertain early whether any constituents fall outside of the compositional limits determined for other more well characterized sludges. Furthermore, even though sludge will undergo treatment prior to being deposited in the Hanford Waste Tanks, documentation of feed material to the process will almost certainly be necessary.

The above sludge related issues will be addressed through a campaign to collect samples from 25 locations in the $K$ East and $K$ West Basins including adjacent pits. Sufficient sludge will be retrieved to ascertain chemical, radiological, and physical properties of the sludge. The volume of sludge collected will also be sufficient to feed future testing of the pretreatment process. 
HNF-2033, Rev. 0

CONTENTS

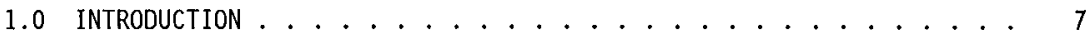

2.0 DATA QUALITY OBJECTIVES PROCESS ................... 9

2.1 STATE THE PROBLEM AND REVIEW PREVIOUS DATA . . . . . . . . 9

2.2 IDENTIFY THE DECISIONS . . . . . . . . . . . . . . . 10

2.3 INPUTS TO THE DECISIONS ............. 11

2.3.1 Properties in Support of the Sludge Treatment

Process Design ............... 11

2.3.2 Treatment Process Demonstration ......... 11

2.3.3 Measurements Supporting Acceptance by Tank Waste

Retrieval System .............. 12

2.3.4 Other Measurements . . . . . . . . . . . . . . . 12

2.4 BOUNDARIES OF THE STUDY .............. 12

2.4.1 Equipment and Sampling Procedure . . . . . . . . 13

2.4.2 Sampling Strategy ............. 13

2.5 DECISION RULES .............................. I4

2.6 DECISION ERRORS . . . . . . . . . . . . . . . 15

2.6.1 Programmatic Errors ............. 15

2.6.2 Errors in Sampling and Analysis .......... 15

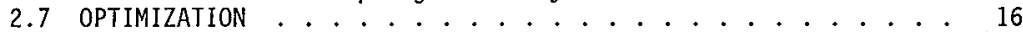

3.0 REFERENCES . . . . . . . . . . . . . . . 17

APPENDIX A LIST OF STAKEHOLDERS . . . . . . . . . . . 35 
HNF-2033, Rev. 0

\section{LIST OF FIGURES}

2.1. Status of Characterization in K East Basin . . . . . . . 27

2.2. Status of Characterization in $\mathrm{K}$ West Basin ......... 28

2.3. Maximum Depths of Sludge in K West Basin . . . . . . . . . 29

2.4. Average Depths of Sludge in K West Basin . . . . . . . . . 30

2.5. Schematic of Floor Sludge Samples . . . . . . . . . . 31

2.6. Sampling Locations in K East Basin ... . . . . . . . 32

2.7. Sampling Locations in K West Basin ............ 33

\section{LIST OF TABLES}

2.1. Summary of Previous S7udge Sampling Campaigns .......... 21

2.2. Amounts of Sludge in $\mathrm{K}$ East and $\mathrm{K}$ West Basin Attributed to Various Sources ............... 21

2.3. Areas Proposed for Current Sampling Campaign . . . . . . . . 22

2.4. List of Physical, Chemical, and Radionuclide Properties to be Measured for Basin Floor and Pit Sludge Samples Recovered from K East and $\mathrm{K}$ West Basins ............ 23 
HNF-2033, Rev. 0

This page intentionally left blank. 
HNF-2033, Rev. 0

\section{DATA QUALITY OBJECTIVES FOR SAMPLING OF SLUDGE FROM THE $K$ WEST AND $K$ EAST BASIN FLOOR AND FROM OTHER BASIN AREAS}

\subsection{INTRODUCTION}

This document defines the data quality objectives (DQOS) for a sludge sampling campaign which encompasses the floor in the 105-K West Basin as we11 as various pits in $\mathrm{K}$ West and $\mathrm{K}$ East Basins. The two $\mathrm{K}$ Basins are waterfilled concrete pools which contain 2,100 tons of $\mathrm{N}$ Reactor metal fuel elements stored in aluminum or stainless steel canisters. Associated with this Spent Nuclear Fuel (SNF) is an accumulation of particulate layered material which is generally called sludge. Sludge is found on the basin floors, in canisters, and in the basin pits which are used for miscellaneous tasks such as cask handling. In fact, several different types of sludge exist (Pearce 1998b) depending on which basin, canister type, or pit location that the particular sludge is found. Each type of sludge is a unique nonhomogeneous mixture possibly containing corroded fuel, debris such as windblown sand or insects, rack and canister corrosion products, and/or fission products (Johnson 1995).

A11 of the various sludges will need to be transported away from the $K$ Basins and disposed of as envisioned in the Integrated Process Strategy for Fuel and S7udge Disposition documents (Fulton 1994; WHC 1995; A7derman 1995). Different types of sludge however may have markedly different characteristics and disposal paths. This document will address the characterization strategy for those types of sludge not previously characterized or discussed in previous DQO documents. It should be considered a supplement to the DQOS for $K$ East floor and canister sludge and for $K$ West canister sludge (Makenas 1995; Makenas 1996a, 1996b) in that it seeks to ascertain those characteristics of siudge which are unique with respect to those properties a Tready determined for canister and K East Basin floor sludge. Recent decisions, Sellers 1997, have resulted in the need for treatment of the sludge prior to its currently identified disposal path to the Hanford waste tanks. This has resulted in a need for supplemental characterization of the sludge material as well as subsequent process development testing for the treatment system (Pearce 1998a).

It is recognized that, due to the accelerated nature of the SNF project, disposal pathway designation and design of a sludge treatment system are proceeding in parallel with characterization and thus, the data acquired may Tead to changes in existing project assumptions. The DQO methodology followed in this document is that defined in the K Basin Project DQO Strategy Document (Lawrence 1994) with the various standard DQO questions addressed in sequence in the following discussions. Since NUMATEC Hanford currently has the lead in siudge processing their approval is sought on this DQO document in Tieu of the Pacific Northwest National Laboratory (PNNL) signature suggested in Lawrence (1994). This Reference Strategy Document is based on Environmental Protection Agency (EPA) guidance (EPA 1994) but it notes the parts of the process which must be modified for a project, such as SNF, which seeks to determine bounding conditions for design and transportation alternatives. A list of stakeholders in this effort is given in Appendix A. 
HNF-2033, Rev. 0

This page intentionally left blank. 
HNF-2033, Rev. 0

\subsection{DATA QUALITY OBJECTIVES PROCESS}

The following seven major sections, 2.1 to 2.7 are the seven steps in the DQ0 process.

\subsection{STATE THE PROBLEM AND REVIEH PREVIOUS DATA}

The existence of sludge on the floor and in canisters for both $\mathrm{K}$ East and $K$ West Basins has been documented during various sludge depth measurement campaigns (Baker 1994; Maassen 1997a). Figures 2.1 and 2.2 and Table 2.1 summarize the various types of sludge, their locations and characterization status. It can be seen that characterization information is greatest for $K$ East floor/pit sludge as well as for both $K$ East and $K$ West canister sludge. Pertinent knowledge is minimal for $K$ West floor and pits. A very recent study (Maassen 1997a, 1997b) has ascertained the depths of sludge found in these heretofore uncharacterized locations (Figures 2.3 and 2.4). Table 2.2 indicates the relative amounts of total sludge volume attributed to the various types of sludge.

Sludges have been found which are high in iron ( $K$ East floor), high in uranium ( $K$ East and $K$ West canisters) and high in sand (K East north load out pit) (Warner 1994). They have been found to contain varying amounts of hazardous constituents such as PCBs as we11 as many unregulated trace compounds. Pieces of graphite (in K West canisters) and resin beads (in $K$ East floor, pits, and canisters) have also been encountered.

The problems related to sludge to be addressed by the current DQO are:

1. The proposed sludge treatment process must confront all of the various sludges in the two basins. Figures 2.1 and 2.2 indicate those sludges where no information is available to date. It is meant to safely alter particle size and el iminate pyrophoric constituents, polychlorinated biphenyls (PCBs), and nonradiolytic gas generation. Various dilution, chemical addition, and precipitation steps are envisioned. It should be ascertained whether any of the sludge types contain constituents incompatible with currently envisioned processes. This should be accomplished before (1) the treatment process/equipment final design is completed and (2) before the sludges are commingled because it is not currently planned to have a separate processing run (or conditions) for all 14 identified types of sludge.

2. The effectiveness of sludge treatment is being demonstrated in various laboratory-scale and pilot-scale tests (Delegard 1998; Pearce 1998a) prior to treatment being initiated for the bulk of the basin sludge. Currently there is not enough sludge in the Taboratories (left over from previous specific characterization campaigns) to perform the tests that are proposed (Delegard 1998) and furthermore not all of the possible types of sludge are represented in current archive material (Baker and Schmidt 1998). The sludge may also have become dry during storage with unknown consequences for future testing. 
3. The knowledge of sludge chemical composition, radiological properties, and physical properties is incomplete. Although several types of sludge have been sampled and analyzed (Makenas 1996c, 1997a, 1998), areas of the basin remain where no analyses have been performed. It may be necessary to have a working knowledge of sludge composition to obtain approvals and permits to ship and handle sludge. Although the types of sludge remaining to be characterized are assumed to be less aggressive and less voluminous than those already investigated, it is still prudent to test this assumption and ascertain early whether any constituents fall outside of the compositional 7 imits determined for other more well characterized sludges. Furthermore, even though sludge will undergo treatment prior to being deposited in the Hanford Waste Tanks, documentation of feed material to the process will almost certainly be necessary.

\subsection{IDENTIFY THE DECISIONS}

The decisions which must be made by the SNF project for sludge retrieval/ disposal and which are partially addressed by the current characterization effort are listed below. The complete closure of these decisions will require evaluation of these data along with data from previous campaigns for floor and canister sludge, from a current campaign for fuel element coating material (which may combine with sludge) and from a future campaign envisioned to collect additional canister sludge. The decisions are not interdependent and should be pursued in parallel.

1. Does the sludge in previously uncharacterized areas of the basin add anything that will thwart the goals of the treatment process as it is currently envisioned? Examples would be constituents which prevent or hinder desired dissolutions or precipitations of components or which would imply a safety hazard. Based on constituents found either the design of the treatment process will be altered or no change will be required.

2. Does the proposed sludge treatment process work on a Targe scale (i.e., with the amount and variability of sludge currently in the basins)? The extent of testing and size of sample batches necessary to demonstrate this scaleability is not yet determined. This work wi1], for the most part, be done under its own specific set of DQOS (Pearce 1998a). The object of the current effort is only to supply enough non-canister material in one campaign to anticipate the needs of this demonstration since frequent sampling campaigns are neither timely nor economically feasible. This would include sludge from previously and newly characterized basin areas.

3. Does $K$ West floor sludge and the sludge from previously uncharacterized $K$ East and $K$ West pits contain any constituents outside of the bounds set by current sludge process flow diagrams (Flament 1998). The resolution of this question will be the submittal of new process flow diagrams and updates to the sludge data book following laboratory analysis covering the sludge collected 
in this campaign with modification of previous flow diagrams and data book entries only if new data for other locations warrants the change. It should be noted that the amount of fuel constituents, which will be added to the sludge during the canister cleaning associated with removal of fuel from the basin, currently has a large uncertainty. This uncertainty in the final composition of generic sludge is not addressed in this document.

\subsection{INPUTS TO THE DECISIONS}

Information to make the above decisions will be acquired through sampling of sludge from the floor and pits in the $K$ East and $K$ West. Those areas of the basins which are proposed as areas to be sampled for this campaign are listed in Table 2.3. Note that some of the areas proposed for sampling, due to their inaccessibility or low sludge volume, will provide fewer samples than others. Areas of the basins will provide multiple samples which give confidence that properties measured are representative of an entire area. Areas with the most voluminous amounts of sludge will provide the bulk of the sludge needed for process demonstration activities.

Values for the various properties needed for the decisions will be obtained through shipment of the samples to laboratories with demonstrated capabilities for the needed analyses.

\subsubsection{Properties in Support of the S1udge Treatment Process Design}

The treatment process will alter both the particle size and the chemical state of the sludge: To demonstrate a successful process, on any scale, one obviously needs to know the input to and the output from the process. Analyses of sludge covered by this DQO seek to cover the input to the process while measurements of output characteristics are specified in Pearce and Delegard (1998). Properties 1isted in Table 2.4 include those needed for successful treatment process characterization. Chief among these will be particle size, elements known to be of concern to the process design (for example $\mathrm{Fe}$ and $\mathrm{Pu}$ ), and $\mathrm{PCB}$ content. Iriformation developed from this characterization will be used to refine current estimates of the feed stream compositions being used for the design basis of the treatment process (Pearce 1998b).

\subsubsection{Treatment Process Demonstration}

Support for process demonstration work (Pearce 1998; Delegard 1998), in the current effort, will consist primarily of furnishing, to the designated laboratory, sufficient quantities of sludge to meet the needs of the demonstration. These needs are defined in reference (Schmidt 1998). The amounts to be recovered from the basins for process demonstration as well as those amounts needed for the properties determinations discussed above are given in Table 2.3. Some additional characterization of sludge sample materials provided for treatment process development (process flow diagrams) and ultimate equipment design in specific areas of concern to these activities is expected. 


\subsubsection{Measurements Supporting Acceptance by Tank Waste Retrieval System}

Acceptance of sludge by TWRS is directly dependent on the review by Tank Farms Process Engineering of sludge properties listed in sludge treatment process flow diagrams. Such a process is in-place to ensure that sludge will not react excessively with existing tank waste and not be of a composition which is outside of existing permits or that further complicates ultimate disposal of the tank waste. Furthermore, sludge must remain in a transportable state while being retrieved, stored, pretreated, and residing in the tanks to facilitate final disposition of the waste. Previous process flow diagrams will be revised only if new data indicate sludge properties which are outside of previously assumed bounds. The characteristics needed to complete the updated process flow diagrams lead to the analyses, listed in Table 2.4, to be performed on the acquired sludge. Primarily these consist of wet chemistry techniques to ascertain radionuclide and hazardous metal constituents. In addition, a most important analysis will be $X$-Ray Diffraction which may give an indication of chemical phases which may affect the sludge treatment process. Analysis for PCBs will also be performed since these have been encountered in previous sludge analysis campaigns. Furthermore, the determination of particle size is considered significant from a criticality standpoint.

\subsubsection{0ther Measurements}

In addition to properties related to the above three decisions, Table 2.4 also 1 ists properties which are applicable to adjunct issues such as water clarity during basin activities and the acquisition of air permits for in-basin work. These are not covered in the decisions 1 isted in Section 2.2 and should be regarded as supplemental information.

Also included in Table 2.4 are physical properties needed to support the transportation and handling of sludge. It is anticipated that the discharging of sludge at TWRS will not be performed using the existing tank receiving station and thus the effects of sludge on existing TWRS 1 ines is not an issue. Physical property information will, instead, feed the design and operation of equipment dedicated solely to the removal of sludge from $K$ Basin.

\subsection{BOUNDARIES OF THE STUDY}

This Sampling Campaign will be done within the manpower availability of $\mathrm{K}$ Basin operations staff and within SNF budget constraints. Operations personnel will run the sampling equipment and perform those tasks (such as cask loading) needed to accomplish shipment of samples to laboratories. Operations will also need to support the training and readiness review processes for this activity. The work will be performed utilizing practices which conform to ALARA for radiation dosage to workers and performed within the limits of the K Basin Safety Analysis Report. The near term need for data on floor sludge has led to use of equipment with a radiation dose limit (Baker 1995b) of $7 \mathrm{R}$ to $10 \mathrm{R}$ per hour at $5 \mathrm{~cm}$ (2 in.) from a $125 \mathrm{~m} \ell$ to $500 \mathrm{~m} \ell$ sample. In instances where funding limitations constrain the amount of 
laboratory analysis, characterization for waste tank acceptance and treatment will be given priority over solid waste. Disposal of sludge in waste tanks, with treatment, is currently the selected alternative when compared to direct disposal as solid waste.

Tests for PCBs should be performed prior to other chemical analyses. A negative result from such a test will significantly reduce costs attributed to the handling of laboratory waste. Any archive sludge material, not utilized in examinations and/or destined for future process testing shall be stored in a manner which does not allow the sludge to dry out.

This sampling campaign will be performed after completion of the coating brushing campaign in $\mathrm{K}$ Basins (Makenas 1997b) and prior to the next campaign to recover sludge from canisters.

\subsubsection{Equipment and Sampling Procedure}

The samples of sludge are to be retrieved using an apparatus whose design criteria are outlined in (Baker 1995b). Samples of sludge are to be pumped from the Basin water pool to a point above the grating for collection in containers. The basic concept is shown schematically in Figure 2.5. This apparatus is a more sophisticated version of the mechanism that was used to acquire early limited sludge samples. Acceptance testing for the equipment is outlined in reference (Bridges 1997) and essentially consists of demonstrations in the 305 Building poot utilizing a rudimentary sludge simulant.

Operation of the envisioned equipment in $K$ East and $K$ West Basins will require that an isolation tube be inserted into the sludge prior to sampling and that sludge be vacuumed nearly completely and exclusively from within the isolation tube [at least $85 \%$ recovery for particles less then $0.64 \mathrm{~cm}$ ( 0.25 in.) in diameter as confirmed by acceptance testing done outside of $K$ Basins]. Since the sludge is multi-layered, dealing with this isolation column of siudge will prevent selective sampling of only one particular layer at the expense of other layers. It is expected that in areas of very shallow sludge the isolation tube will be moved periodically during the collection of a single sample or, if need be, the isolation tube will be eliminated or modified to allow sufficient sample to be collected by a free collection method. In such a case, special collection canisters which minimize entrained water and maximize accumulated sludge may be utilized. An example of such a canister would be one with a filtered outlet port.

\subsubsection{Sampling Strategy}

STudge will be sampled from 25 locations (representing nine different types of sludge) as listed in Table 2.3. These approximate locations are shown in Figures 2.6 and 2.7. More specific location information (such as sampling near a specific fuel canister or rack location) will be given in the Sample Analyses Plan (SAP) (We1sh 1998). These locations represent those areas of the basin from which no data exist and those specified in Schmidt (1998) as the source of additional sludge needed for tests of the sludge treatment process. 
Reference (Schmidt 1998) Tists a number of sludge samples, sample volumes and locations which will satisfy the needs of various treatment demonstration phases. These estimates have specifically not included material for general characterization of sludge in Basin areas where previous data do not exist. Thus Table 2.3 has been constructed by expanding the number of samples suggested in (Schmidt 1998) but not in a manner which ascribes specific samples to characterization and specific samples to treatment. Rather, it is assumed that a portion of the recovered sludge material will be apportioned from the expanded number of samples for use in characterization while holding constant the amount of material avajlable for treatment exercises. While the amount of sludge in a sample can be controlled to some extent by isolation tube diameter, the estimated amount of sludge recovered with each sample is generally expected to vary such that areas with deep sludge are more likely to yield copious quantities in a single sample. Schedule and budgetary considerations may not allow the shipment of 25 discreet samples to laboratories across the Hanford Site. Combining of samples, at the basin or pits, from two or more neighboring locations shown in Figures 2.6 and 2.7 is permitted. Only samples from the same pit or from the floor of the same basin may be combined. Mixing of floor and pit samples in one sample container is not permitted. Combining of samples at the laboratory, rather than at the basins, is also permitted subject to the same restriction against combining floor and pit samples.

\subsection{DECISION RULES}

The decisions which are to be made by the SNF project for siudge treatment and disposal and which are partially addressed by the current characterization effort are listed below. The decisions are not interdependent and should be pursued in parallel.

1. If the new types of sludge collected here contain constituents whose chemical, physical, and radiological properties (as 1isted in Table 2.4) are not compatible with the current treatment process then that process will be modified to treat the unforseen constituents (otherwise no change to the process is required). The reference process is essentially defined by the completion of the process flow diagrams issued as reference Flament (1998) by Numatec Hanford Company. These and the Design Basis Feed Description (Pearce 1998b) have determined the nominal and bounding process conditions and compositions of five different sludge streams. Assessments of adequacy of these bounds may be made by direct comparison of characterization data with process assumptions or may be shown by smal1-scale demonstrations, using actual sludge, of processes (such as dissolution). The current DQO provides only the material for this latter small scale determination where as the actual demonstration is addressed in a separate DQO document (Pearce 1998).

2. If enough non-canister sludge can be provided (satisfying amount specified in Table 2.3) then there will be sufficient material for testing on the desired scale. When the sludge treatment process (which is assumed to have been demonstrated on a small scale for 
HNF-2033, Rev. 0

well characterized material discussed above) can be shown to work on larger amounts of material (quantities currently undefined) then detailed design and construction of the actual sludge treatment system will proceed. Again, the current DQO document provides only the material for such a large scale demonstration whereas the throughput and product quality requirements for the demonstration will be specified elsewhere.

3. If the constituents (1isted in Table 2.4) of newly examined forms of sludge fall outside of the chemical, physical, and radiological bounds set by previous process flow diagrams, revised process flow diagrams will be issued (otherwise they will not).

\subsection{DECISION ERRORS}

Two types of errors can be identified which are related to the canister sludge sampling effort: those that influence the programmatic success of the Sludge Disposition Path (i.e., prevent the successful removal of sludge from the basin to a disposal site in a timely cost-effective manner) and those that are associated with individual sampling and analytical methodologies.

\subsubsection{Programmatic Errors}

If radiochemical and physical properties of $K$ West floor and other related sludges are not further defined (or are defined incorrectly), then the design of sludge processing equipment will proceed with only the data available at this time. This increases the risk that the amount of one or more sludge constituents will not be enveloped by the equipment capabilities and operational/regulatory scenario or that the equipment will need to be over designed for all conceivable eventualities with resulting cost increases. If decisions on the acceptability of sludge for burial as solid waste or storage in waste tanks are not made with data that includes all the various sludges, the risk increases that a decision to deposit sludge as solid waste or in tanks will be countermanded by subsequent analyses of the retrieved and transported sludge (with the resultant waste of resources, time, and effort). Finally, if the material is not provided for treatment, then functionality of the system (actual application) and efficiency of design will be at risk.

\subsubsection{Errors in Sampling and Analysis}

The 25 sample locations proposed, taken together with sludge sample from previous campaigns give a general representation of sludge in the basins. They will furnish confirmation that the current baseline components and properties bound the actual condition of $K$ Basin sludge by ensuring that all forms of sludge have been examined.

Reference (Fowler 1995a, Revision 1) specifies that criticality, flammability, and energetics properties necessary for waste tank acceptability decisions need to be known to the $90 \%$ confidence level. Corrosion related 
data must be known to $80 \%$ confidence. However, all of these will be modified by the currently anticipated sludge treatment process. No other guidance is available from the other users of the data nor has an acceptable programmatic risk been quantified. Since regulatory (RCRA) sampling is not a goal of this current effort, laboratory good-practice standards are judged to be acceptable (Fowler 1995b). An effort is underway by Welsh, et al., to quantify laboratory accuracies for individual analytes which wili lead to the required confidence levels and provide valid comparisons to previous floor sludge data. This study will be included in the SAP (Welsh 1998) to be published as a separate document at a later date.

\subsection{OPTIMIZATION}

The reader may want to refer to Pearce (1998a) for risks related to sludge treatment characterization data needs and the need for additional sample material.

The target sample volumes listed in this DQO satisfy, to the extent possible, the needs specified in Schmidt (1998) for the pretreatment project. The analytes and properties measured are those of interest to TWRS and sludge recovery. Coverage of the various areas of the basins is sufficient to give confidence that the general character of sludge will be known.

If the current sludge characterization effort is successful (both specific characterization and treatment testing of samples) in adequately bounding the properties of sludge in $K$ West Basin and in remote areas of $K$ East Basin then a future characterization campaign will concentrate on siudge from $K$ East and $K$ West canisters. Canister sludge samples will be shipped to hot cells with the intent of supplying larger quantities of canister sludge for treatment demonstration than were retrieved in previous canister sludge characterization campaigns.

At this writing there are no plans to acquire sludge which is completely prototypic of that to be generated in the fuel cleaning process and fed to the sludge treatment streams. However, some data related to this issue is being generated in a parallel effort (Makenas 1997b) to analyze subsurface sludge recovered from corroded fuel elements recently probed during hot cell examinations or sludge recovered from fuel element shipping containers. chemistry and physical properties are currently being acquired from these s] udges. 


\subsection{REFERENCES}

Alderman, C. J., 1997, "K West Canister Sludge Waste Data Package Submittal," Letter DESH-9758602 to J. G. Kristofzski, dated September 25, 1997, Duke Engineering \& Services Hanford, Inc., Richland, Washington.

Alderman, C. J., 1995, Recommended Strategy for K Basin S7udge Disposition, WHC-SD-SNF-SP-00I, Rev. 0 (Transmitted via Letter 9552284, J. C. Fultion to C. A. Hansen dated April 24, 1995), Westinghouse Hanford Company, Richland, Washington.

Baker, R. B., 1998, Sludge Sample Availability for Testing; Appendix C to Reference Pearce 1998, Duke Engineering \& Services Hanford, Inc., Rich] and, Washington.

Baker, R. B., 1995, System Design Description: Sampling Equipment for K Basin Floor S7udge, WHC-SD-SNF-SDD-003, Rev. 0, Westinghouse Hanford Company, Richland, Washington.

Baker, R. B., 1994, Summary Status of K Basins Sludge Characterization, WHC-SD-SNF-TI-006, Rev. 0, Westinghouse Hanford Company, Richland, Washington.

Bredt, P. R. and D. E. Reinhart, 1996, Summary of K East Basin S7udge Gas Sampling Results, Pacific Northwest National Laboratory, Richland, Washington.

Bridges, A. E., 1997, Acceptance Testing for Floor S7udge Sampler, to WHC-SD-SNF-TRP-008, Rev. OA, Westinghouse Hanford Company, Richland, Washington.

Delegard, C. H., C. D. Carlson, A. J. Schmidt, and K. L. Silvers, 1998, $K$ Basin S7udge Materials Treatment Testing Strategy, HNF-1926, Rev. 0, Pacific Northwest National Laboratory, Richland, Washington.

EPA, 1994, "Guidance for Planning for Data Collection in Support of Environmental Decision Making Using the Data Quality Objectives Process," U.S. Environmental Protection Agency, EPA,QA/G-4.

Flament, T. A., 1998, SNF Project Sludge Treatment System Process Flow Diagram, H-1-81170, EDT 625270, Numatec Hanford Corporation, Richland, Washington.

Fowler, K. D., 1995a, Data Quality Objectives for. Waste Compatibility Program, WHC-SD-WM-DQO-001, Rev. 1, Westinghouse Hanford Company, Richland, Washington.

Fowler, K. D., 1995b, Information for Sample Plan," cc:Mail to K. L. Pearce, May 30, 1995, Westinghouse Hanford Company, Richland, Washington.

Fulton J. C., 1994, Hanford Spent Nuclear Fuel Project Recommended Path Forward, WHC-EP-0830, Volume 1, Rev. 1, Westinghouse Hanford Company, Richland, Washington. 


\subsection{REFERENCES (Continued)}

Johnson, A. B. and S. P. Burke, 1995, K Basin Corrosion Program Report, WHC-EP-0877, Westinghouse Hanford Company, Richland, Washington.

Lawrence, L. A., 1994, Spent Nuclear Fuels Project Characterization Data Quality Objectives Strategy, WHC-EP-0795, Rev. 0, Westinghouse Hanford Company, Richland, Washington.

Maassen, D. P. and N. R. Roe, 1997a, Floor S7udge Depths and Volumes of the 105-K East and $K$ West Basins, HNF-SD-SNF-TI-054, Rev. 0, Duke Engineering \& Services Hanford, Inc., Richland, Washington.

Maassen, D. P. to R. P. Omberg, 1997b, Internal Memo, "Pictures and Locations of Sludge Depths in the 105-K West Basin Pits and Discharge Chute," Duke Engineering \& Services Hanford, Inc., Richland, Washington.

Makenas, B. J., et a1., 1998, Analysis of S7udge from Hanford $K$ West Canisters, HNF-1728, Duke Engineering \& Services Hanford, Inc., Richland, Washington.

Makenas, B. J., et aT., 1997a, Ana7ysis of Sludge from Hanford $K$ East Basin Canisters, HNF-SP-1201, Duke Engineering \& Services Hanford, Inc., Richland, Washington.

Makenas, B. J., 1997b, Strategy for Analyses of Coatings and Subsurface Sludge Recovered During Hot Cell Examinations of $N$ Reactor Elements, HNF-SD-SNF-SP-021, Duke Engineering \& Services Hanford, Inc., Richland, Washington.

Makenas, B. J., 1996a, Data Quality Objectives for $K$ East Canister S7udge Sampling, WHC-SD-SNF-DQ0-008, Rev. 0, Westinghouse Hanford Company, Richland, Washington.

Makenas, B. J., 1996b, Data Quality Objectives for $K$ West Basin Canister Sludge Sampling, WHC-SD-SNF-DQ0-012, Rev. 0, Westinghouse Hanford Company, Richland, Washington.

Makenas, B. J., et al., 1996c, Analysis of S7udge from Hanford K East Basin and Weasel Pit, WHC-SP-1182, Westinghouse Hanford Company, Richland, Washington.

Makenas, B. J., 1995, Data Quality Objectives for $K$ East Basin Floor and Wease7 Pit Sludge Sampling, WHC-SD-SNF-DQ0-005, Rev. 0, Westinghouse Hanford Company, Richland, Washington.

Packer, M. J., 1998, K Basins Sludge Inventory Composition, HNF-SD-SNF-TI-053, Rev. 0, Duke Engineering \& Services Hanford, Inc., Richland, Washington. 


\subsection{REFERENCES (Continued)}

Pearce, K. L., A. J. Schmidt, W. G. Westra, and R. B. Baker, 1998a, Data Quality Objectives for $K$ Basin Conditioning System Laboratory Testing, HNF-1927, Rev. 1, Duke Engineering \& Services Hanford, Inc., Richland, Washington.

Pearce, K. L., 1998b, 105-K Basin Material Design Basis Feed Description for Spent Nuclear Fuel Project Facilities, Volume 2, (S7udge), HNF-SD-SNF-TI-009, Rev. 1, Numatec Hanford Corporation, Richland, Washington.

Schmidt, A. J., 1998, K Basin Sludge Materials Treatment Test Strategy, Appendix $B$ to reference Delegard 1998, Pacific Northwest National Laboratory, Richland, Washington.

Sellers, E. D., 1997, "K Basin S7udge Storage and Disposal Change Request," Letter 9756731 to H. J. Hatch, dated July 29, 1997, Flour Daniel Hanford.

Warner, R. D., 1994, Safety Evaluation of the P7utonium and Uranium Content of $K$ East Basin Sandfilter Backwash Pit, WHC-SD-WM-TA-152, Rev. 0, Westinghouse Hanford Company, Richland, Washington.

Welsh, T. L., 1998, Sample Analysis Plan for $K$ West Floor and Pit Sludge, to be published, B\&W Protec, Inc., Richland, Washington.

WHC, 1995, Hanford Spent Nuclear Fuel Project Integrated Process Strategy for $K$ Basins Spent Nuclear Fue7, WHC-SD-SNF-SP-005, Rev. 0, Westinghouse Hanford Company, Richland, Washington. 
HNF-2033, Rev. 0

This page is intentionally left blank. 
HNF-2033, Rev. 0

Table 2.1. Summary of Previous Sludge Sampiing Campaigns.

\begin{tabular}{||l|c|c|l||}
\hline \multicolumn{1}{|c|}{ Basin Area } & Date & $\begin{array}{c}\text { Number } \\
\text { of } \\
\text { Samples }\end{array}$ & \multicolumn{1}{|c||}{ Comment } \\
\hline \hline K East North Loadout & 1993 & $14^{*}$ & For USQ resolution \\
\hline K East Floor and Weasel Pit & 1995 & 20 & $\begin{array}{l}\text { After discharge chute material } \\
\text { moved to Weasel Pit but prior } \\
\text { to South Loadout Pit sludge } \\
\text { moving to Weasel Pit }\end{array}$ \\
\hline K East Canisters & 1996 & 9 & $\begin{array}{l}\text { Includes two canisters without } \\
\text { fuel }\end{array}$ \\
\hline K West Canisters & 1996 & 9 & \\
\hline
\end{tabular}

*Basic chemistry only (no particle size, settling, PCBs, etc.) and no residual sample material available for use with treatment testing.

Table 2.2. Amounts of Sludge in K East and $K$ West Basin Attributed to Various Sources. (Exclusive of fuel wash sludge.)

\begin{tabular}{||l|c|c||}
\hline \multicolumn{1}{|c|}{ Source } & $\begin{array}{c}\text { K West } \\
\text { Cubic Meters }\end{array}$ & $\begin{array}{c}\text { K East } \\
\text { Cubic Meters }\end{array}$ \\
\hline \hline Floor & 2.4 & 25.8 \\
\hline Weasel Pit & 0.1 & $12.1^{1}$ \\
\hline North Loadout Pit & 4.4 & 13 \\
\hline Elevator Pit & 0.1 & 3.5 \\
\hline Tech View & $0.3^{1}$ & 1.0 \\
\hline Discharge Chute & 0.1 & 2 \\
\hline Canister Sludge & 3.0 & $13.8^{3}$ \\
\hline
\end{tabular}

${ }^{1}$ Includes sludge recently pumped from South Loadout pits after 1995 sampling.

${ }^{2} \mathrm{~K}$ East discharge chute pumped to Weasel Pit prior to 1995 sampling.

${ }^{3}$ Includes empty canisters. 
HNF-2033, Rev. 0

Table 2.3. Areas Proposed for Current Sampling Campaign.

\begin{tabular}{|c|c|c|c|}
\hline Area & $\begin{array}{c}\text { Number } \\
\text { of } \\
\text { Samples } \\
\end{array}$ & $\begin{array}{c}\text { Target } \\
\text { grams per } \\
\text { Sample } \\
\end{array}$ & Purpose ${ }^{1}$ \\
\hline$K$ East Floor & $4^{2}$ & 400 & Treatment \\
\hline K East Weasel Pit & 2 & 500 & Treatment \\
\hline K East North Loadout Pit & 2 & 350 & Treatment \\
\hline$K$ East Dummy Elevator $P i t$ & 2 & 300 & Characterization and Treatment \\
\hline K East Tech View Pit & 2 & 200 & Characterization and Treatment \\
\hline$K$ West Floor & 5 & 100 & Characterization and Treatment \\
\hline K West North Loadout Pit & $5^{3}$ & 200 & Characterization and Treatment \\
\hline K West Tech View Pit & $2^{3}$ & 200 & Characterization and Treatment \\
\hline$K$ West Dummy Elevator Pit & 1 & 200 & Characterization and Treatment \\
\hline Total & 25 & 6300 & \\
\hline
\end{tabular}

${ }^{1}$ Treatment implies the material will be used for process studies.

Characterization implies the samples address a here-to-for uncharacterized area of sludge.

${ }_{3}^{2}$ Includes one sample with intentionally large concentration of resin beads.

${ }^{3}$ Samples spread between main pit and transfer channeT. 
HNF-2033, Rev. 0

Table 2.4. List of Physical, Chemical, and Radionuclide Properties to be Measured for Basin Floor and Pit S7udge Samples Recovered from K East and K West Basins.

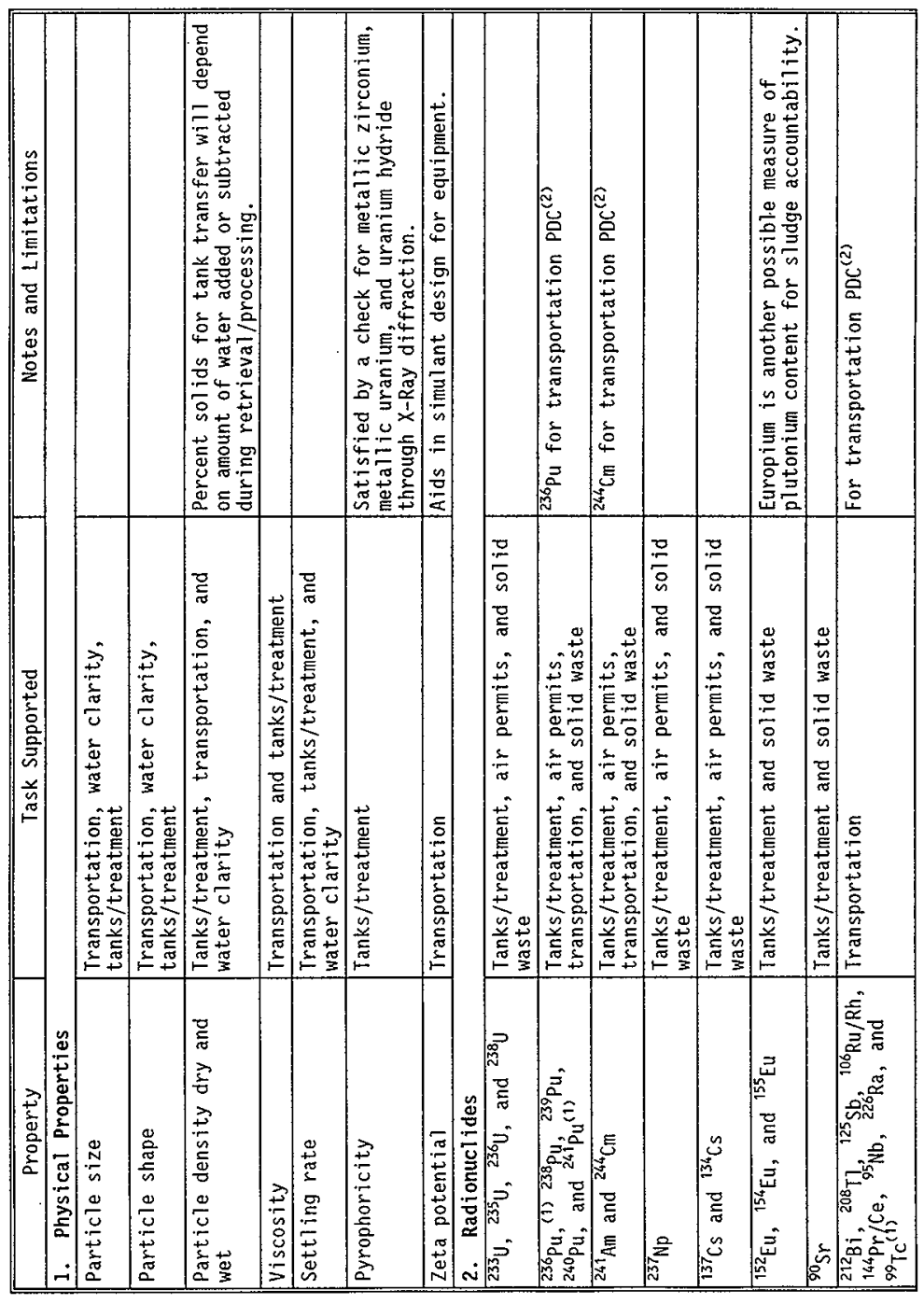




\begin{tabular}{|c|c|c|}
\hline Property & Task Supported & Notes and Limitations \\
\hline \multicolumn{3}{|l|}{ 3. Radiological Properties } \\
\hline Total $\gamma / \beta$ & All, except water clarity & $\begin{array}{l}\text { Radiation levels may be used in radiolysis } \\
\text { calculations. }\end{array}$ \\
\hline Total $\alpha$ & Al1, except water clarity & \\
\hline \multicolumn{3}{|l|}{ 4. Chemical Constituents } \\
\hline Carbonate & Tanks/treatment & $\begin{array}{l}\text { Measurement of total inorganic carbon is } \\
\text { adequate. }\end{array}$ \\
\hline Chloride & Tanks/treatment & \\
\hline Total carbon & Tanks/treatment & \\
\hline TOC & Tanks/treatment & 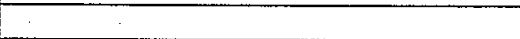 \\
\hline Fluoride & Tanks/treatment & \\
\hline Phosphate & Tanks/treatment and solid waste & \\
\hline Sulphate & Tanks/treatment and solid waste & \\
\hline Polychlorinated biphenyls & Tanks/treatment, air permitting & $\begin{array}{l}\text { Found in floor sludge Reference } \\
\text { (Miller 1995). List other tentatively } \\
\text { identified semivolatile organics compounds. } \\
\text { Special attention should be paid to the } \\
\text { number of solvent contacts as specified in } \\
\text { the SAP. }\end{array}$ \\
\hline U & Tanks/treatment & \\
\hline $\mathrm{Na}$ & Tanks/treatment & \\
\hline $\mathrm{Fe}$ & Tanks/treatment & \\
\hline Al & Tanks/treatment & \\
\hline $\mathrm{Zn}$ & Tanks/treatment & \\
\hline $\mathrm{Pb}$ & Tanks/treatment & \\
\hline $\mathrm{Ag}$ & Tanks/treatment & \\
\hline $\mathrm{Tl}$ & Tanks/treatment & \\
\hline $\mathrm{Se}$ & Tanks/treatment & \\
\hline $\mathrm{pH}$ & Tanks/trea tment & \\
\hline $\mathrm{B}$ & Tanks/treatment & \\
\hline $\mathrm{Ba}$ & Tanks/treatment & \\
\hline $\mathrm{K}$ & Tanks/treatment & \\
\hline
\end{tabular}


जั

\begin{tabular}{|l|l|}
\hline \multicolumn{1}{|c|}{ Property } \\
\hline $\mathrm{Be}$ & \\
\hline $\mathrm{Ca}$ & \\
\hline $\mathrm{Cr}$ & \\
\hline $\mathrm{Cu}$ & \\
\hline $\mathrm{Cd}$ & $\mathrm{Zr}$ \\
\hline $\mathrm{Sand}$ & \\
\hline $\mathrm{Hf}$ & \\
\hline $\mathrm{Mg}$ & \\
\hline $\mathrm{Mn}$ & \\
\hline $\mathrm{Sn}{ }^{(1)}$ & \\
\hline
\end{tabular}

Task Supported
Tanks/treatment
Tanks/treatment
Tanks/treatment
Tanks/treatment
Tanks/treatment
Tanks/treatment
Tanks/treatment
General chemistry tanks/treatment
General chemistry tanks/treatment
General chemistry tanks/treatment
General chemistry tanks/treatment

Fue? braze material and Limitations

Found in floor sludge previously

(2) PDC = Package design criteria. Clad impurity 
HNF-2033, Rev. 0

This page intentionally left blank. 
HNF-2033, Rev. O

Figure 2.1. Status of Characterization in K East Basin.

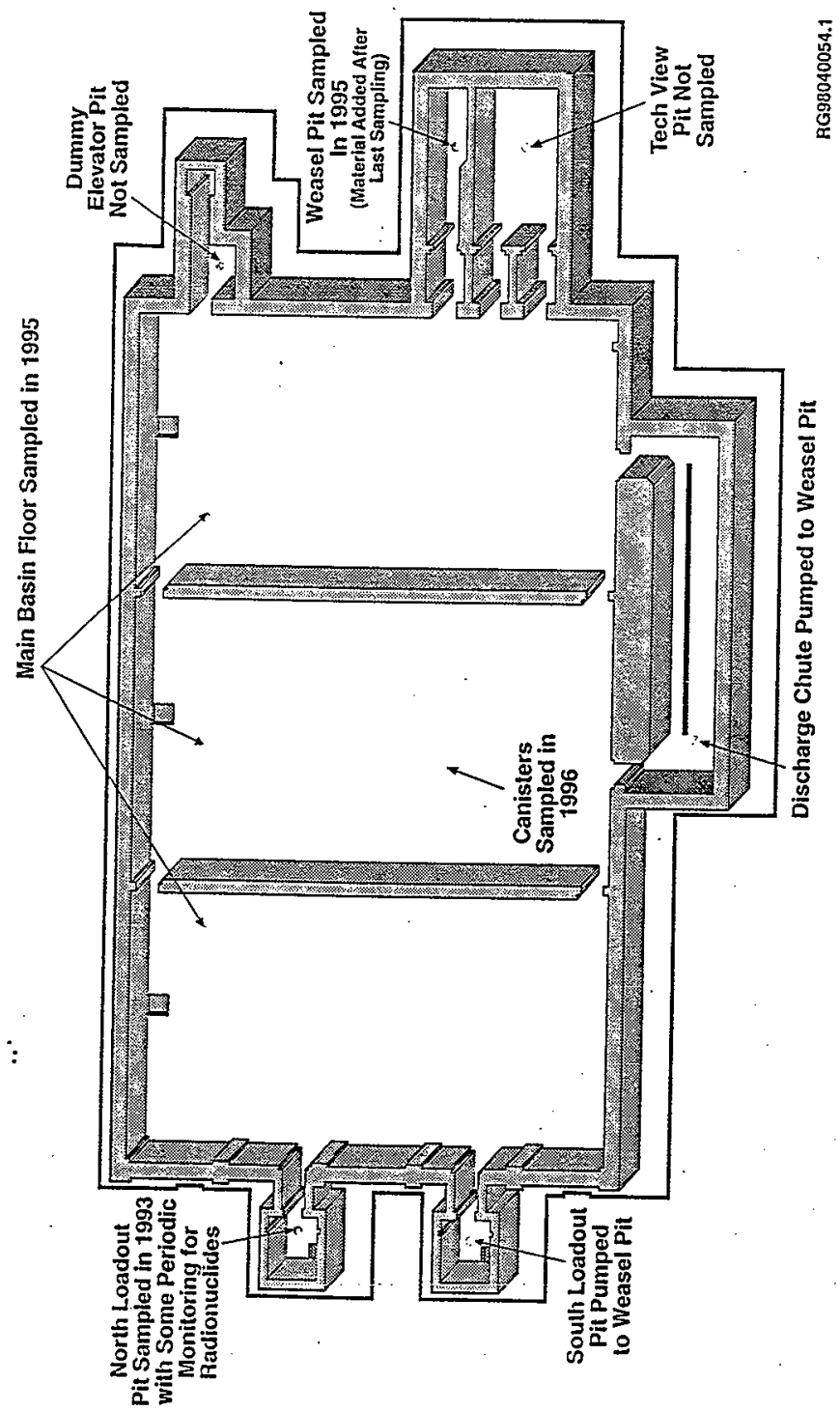


HNF-2033, Rev. 0

Figure 2.2. Status of Characterization in $K$ West Basin.

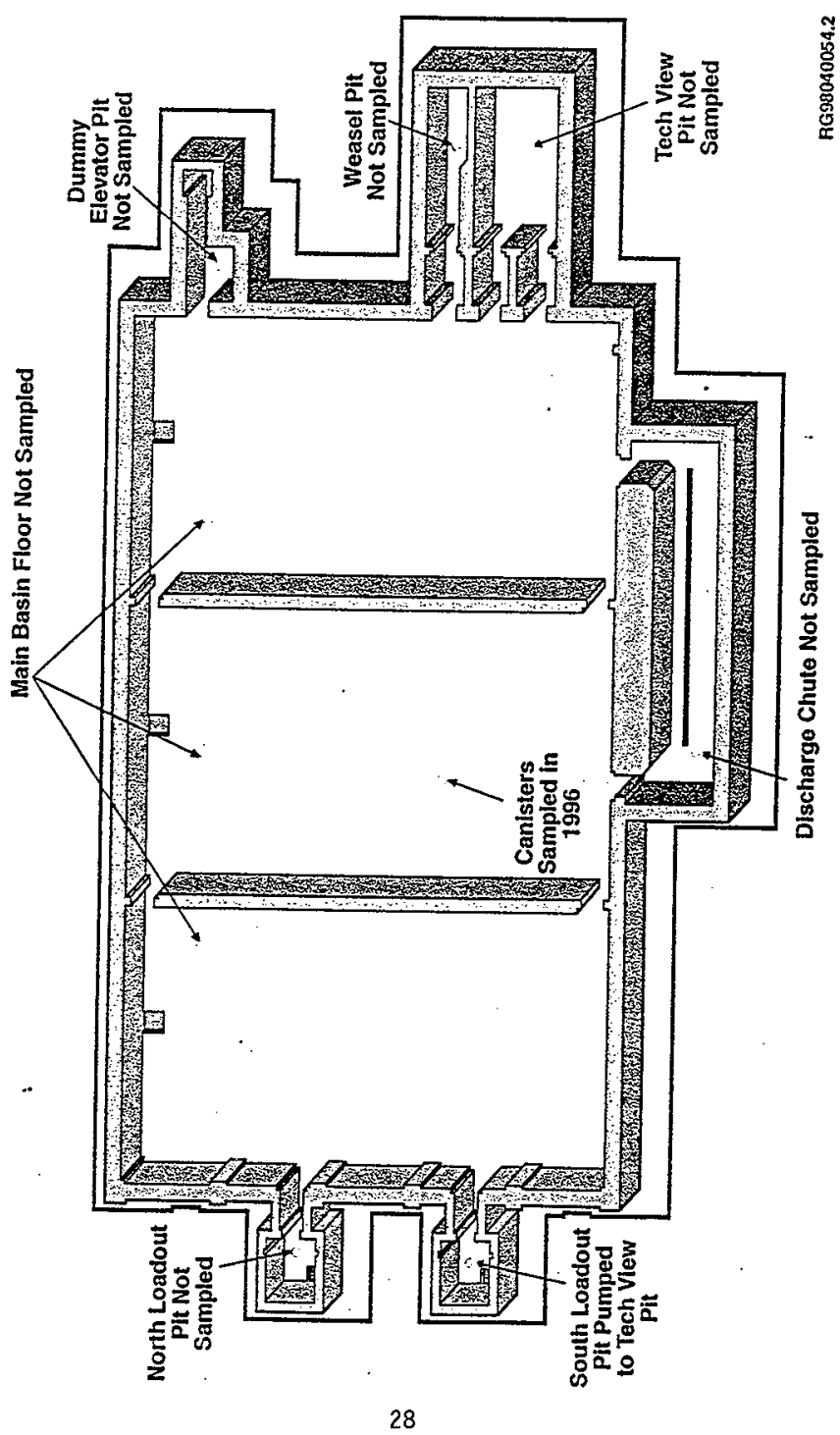


Figure 2.3. Maximum Depths of S7udge in $K$ West Basin (from Reference Maassen 1997b).
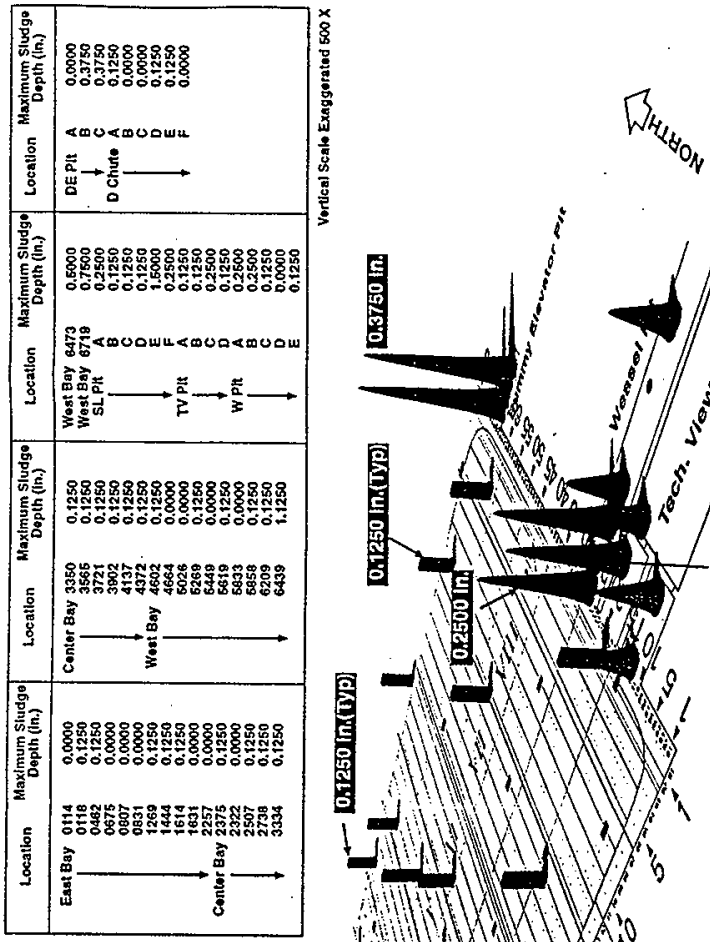
Figure 2.4. Average Depths of Sludge in $\mathrm{K}$ West Basin (from Reference Maassen 1997b). Average is over the width of the measuring ruler (1 foot).

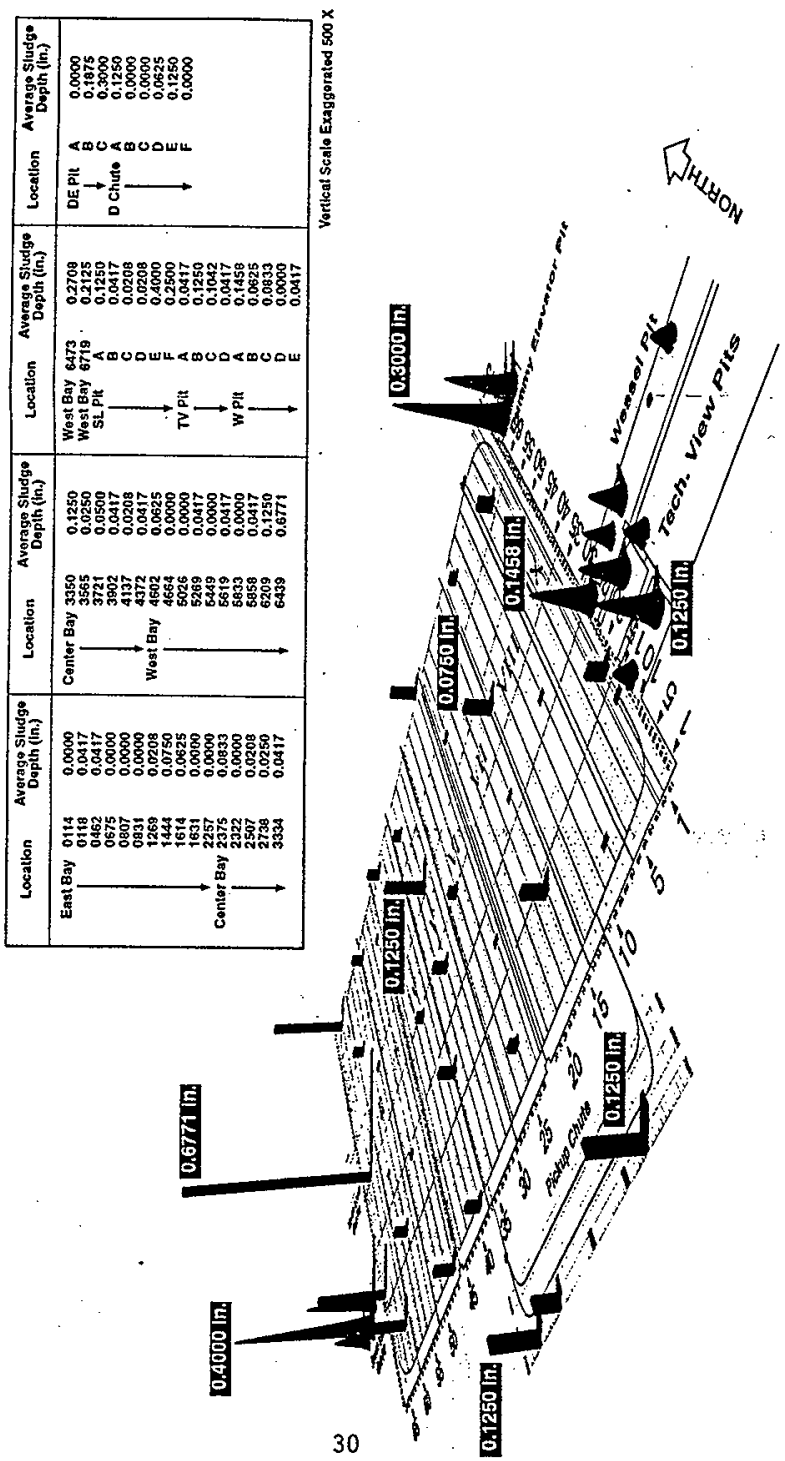


Figure 2.5. Schematic of Floor STudge Sampler.
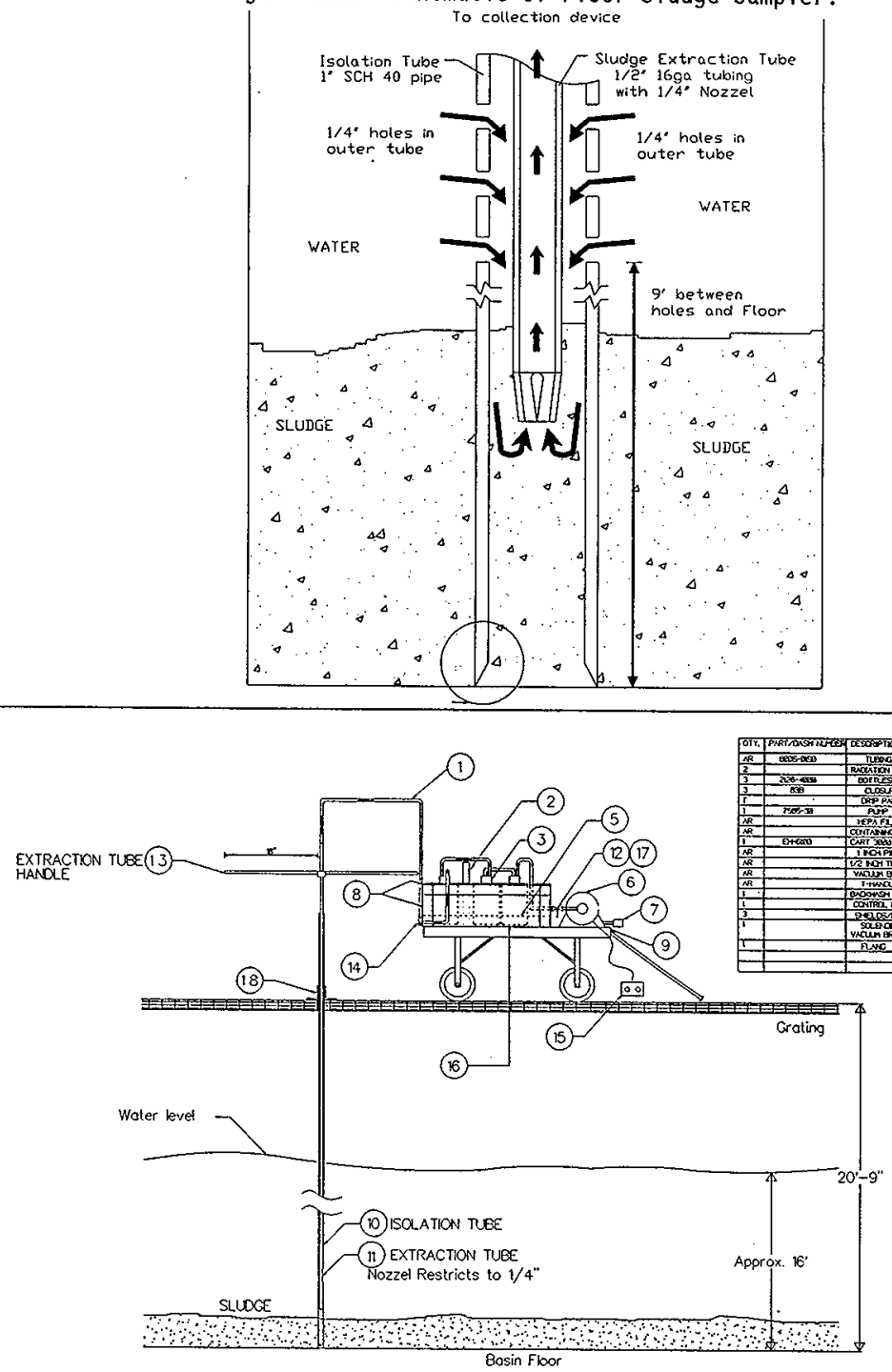
HNF-2033, Rev. 0

Figure 2.6. Sampling Locations in K East Basin.

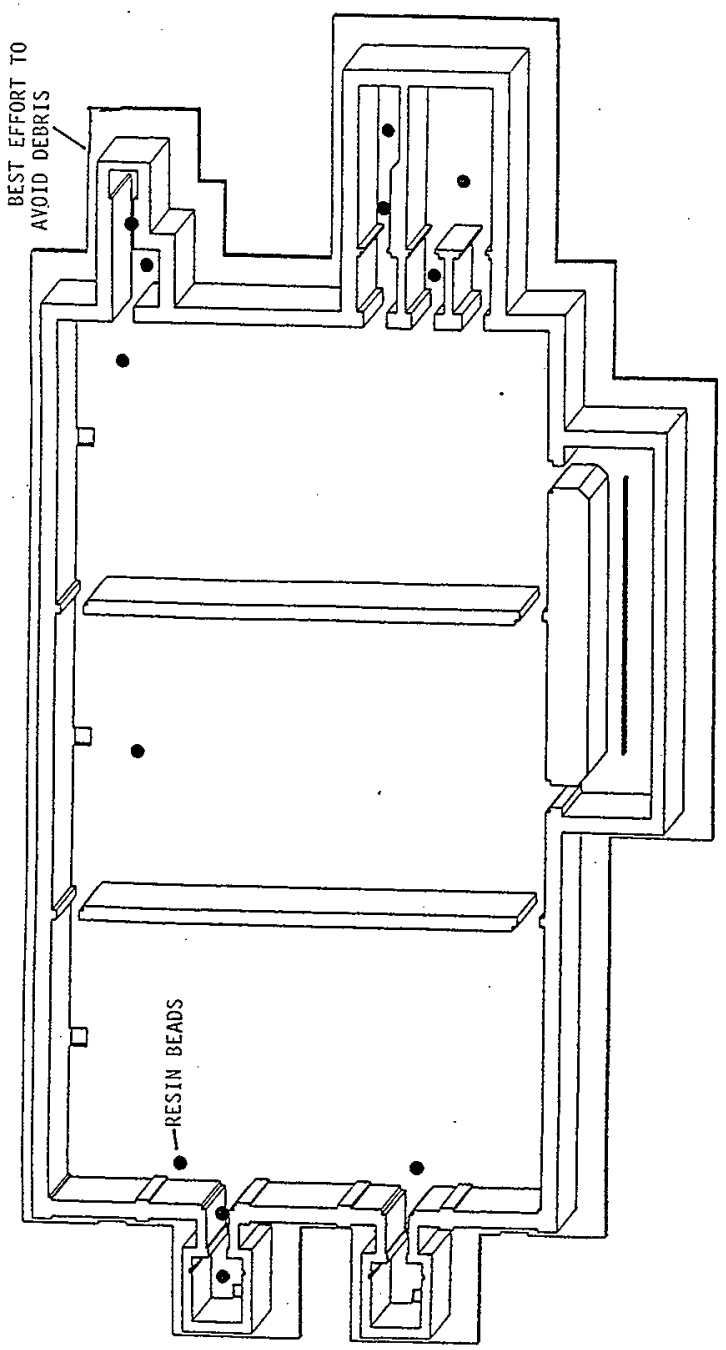


HNF-2033, Rev. 0

Figure 2.7. Sampling Locations in $K$ West Basin.

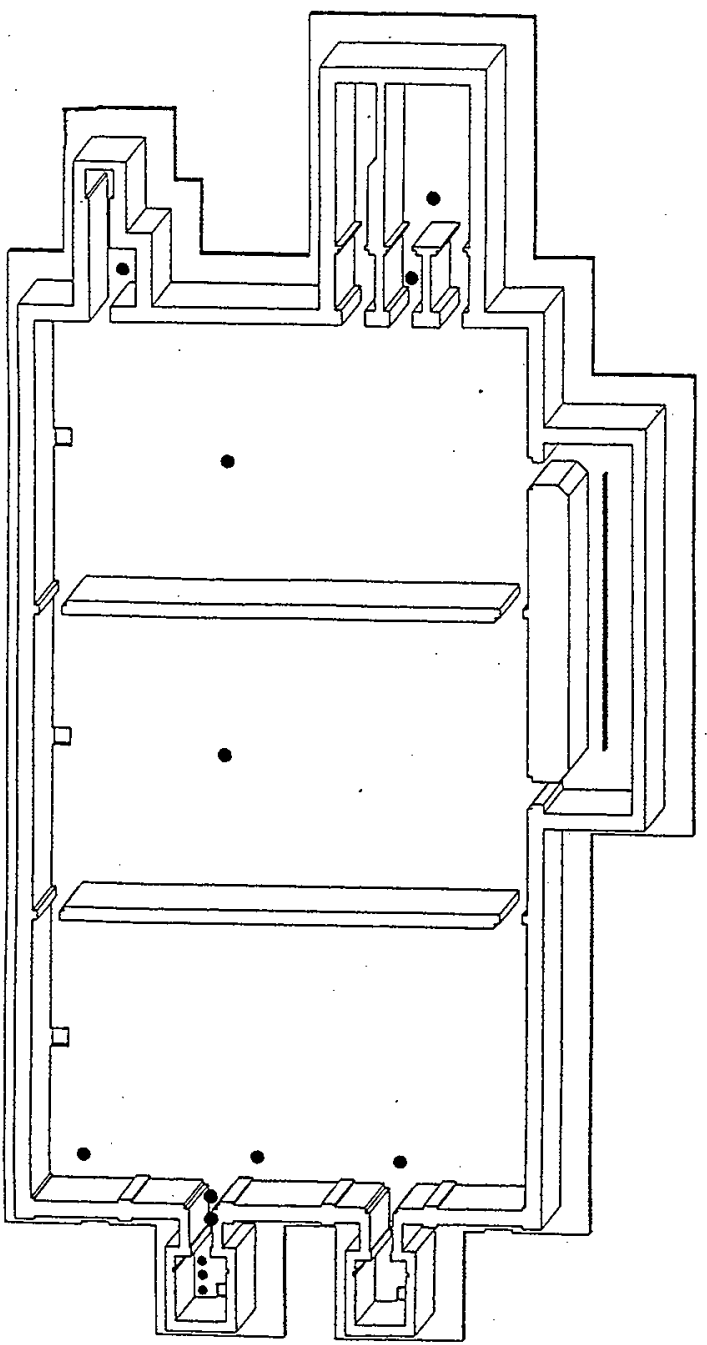


HNF-2033, Rev. 0

This page intentionally left blank. 
HNF-2033, Rev. 0

A P PENDIX A

LIST OF STAKEHOLDERS 


\section{List of Stakeholders for Siudge Sampling}

\begin{tabular}{||l|l|}
\hline Sludge Retrieval & C.J. Alderman and D.R. Precechtel \\
\hline K Basin Operations & W.M. Funderburke \\
\hline Safety Analyses & R.P. Omberg \\
\hline Fuel Process Engineering & C.R. Miska and L.H. Goldman \\
\hline QA & D.W. Smith, M.J. Horhota, and R.P. Ruth \\
\hline Sludge Treatment Chemistry & T.A. Flament, A.G. Westra, and K.L. Pearce \\
\hline TWRS Sludge Disposition Interface & C.H. Delegard and A.J. Schmidt \\
\hline $222-S$ Laboratory & K.L. Pearce \\
\hline 325 Building Laboratory & D.A. Dodd \\
\hline Sampling Equipment Design & K.L. Silvers \\
\hline Sampling Equipment/0perations Interface & A.E. Bridges and P.J. MacFarlan \\
\hline D0E/RL & R.B. Baker and J.J. Jernberg \\
\hline Characterization Management & J. Shuen \\
\hline Sample Analysis Plan & D. W. Bergmann* \\
\hline K West Basin Water Treatment & T.L. Welsh and R.B. Baker \\
\hline Environmental Permitting & K.H. Bergsman and E.J. Shen \\
\hline
\end{tabular}

*Key decision maker. 


\section{DISTRIBUTION SHEET}

\begin{tabular}{|c|c|c|c|c|c|}
\hline To & \multirow{2}{*}{\multicolumn{3}{|c|}{$\begin{array}{l}\text { From } \\
\text { SNF Characterization Project/ } \\
2 \text { F700 }\end{array}$}} & \multicolumn{2}{|l|}{ Page 1 of 2} \\
\hline Distribution & & & & \multicolumn{2}{|c|}{ Date 0ctober 1998} \\
\hline \multicolumn{4}{|l|}{ Project Title/Work Order } & \multicolumn{2}{|c|}{ EDT No. 620818} \\
\hline \multicolumn{4}{|c|}{$\begin{array}{l}\text { Data Quality Objectives for Sampling of Sludge from the } K \text { West } \\
\text { and } K \text { East Basin Floor and From Other Basin Areas/HNF-2033, } \\
\text { Rev. } 0\end{array}$} & \multicolumn{2}{|l|}{ ECN No. } \\
\hline Name & MSIN & $\begin{array}{l}\text { Text } \\
\text { With All } \\
\text { Attach. }\end{array}$ & Text Only & $\begin{array}{l}\text { Attach./ } \\
\text { Appendix } \\
\text { Only }\end{array}$ & $\begin{array}{c}\text { EDT/ECN } \\
\text { Only }\end{array}$ \\
\hline
\end{tabular}

Fluor Daniel Hanford, Inc.
E. W. Gerber
R. L. McCormack
R3-11 X
M. J. Wiemers
R3-11
R3-11
R3-11

$$
x
$$$$
\mathrm{X}
$$
N. H. Williams

B\&W Protec

T. L. We1sh

T4-40 $\quad X$

Duke Engineering \& Services Hanford, Inc.

C. J. Alderman

R. B. Baker

D. W. Bergmann

K. H. Bergsman

A. E. Bridges

L. D. Bruggeman

S. L. Hecht

D. P. Kimball

P. J. MacFarlan

B. J. Makenas

K. R. Morris

A. M. Segrest

J. A. Swenson

C. A. Thompson

D. J. Trimble

SNF Project File

Informatics

J. A. Serles

Lockheed Martin Services, Inc.

$\begin{array}{ll}X 3-74 & X \\ H 0-40 & X \\ H 0-40 & X \\ X 3-85 & X \\ H 0-40 & X \\ H 0-40 & X \\ H 0-40 & X \\ X 3-71 & X \\ H 0-40 & X \\ H 0-40 & X \\ X 3-56 & X \\ \text { R3-11 } & X \\ \text { R3-11 } & X \\ X 3-72 & X \\ H 0-40 & X \\ \text { R3-11 } & X\end{array}$

$\mathrm{HO}-40 \mathrm{X}$

B $-07 \quad X$




\section{DISTRIBUTION SHEET}

\begin{tabular}{|c|c|c|c|c|c|}
\hline \multirow{2}{*}{$\begin{array}{l}\text { To } \\
\text { Distribution }\end{array}$} & \multirow{2}{*}{\multicolumn{3}{|c|}{$\begin{array}{l}\text { From } \\
\text { SNF Characterization Project/ } \\
2 \text { F700 }\end{array}$}} & \multicolumn{2}{|l|}{ Page 2 of 2} \\
\hline & & & & \multicolumn{2}{|c|}{ Date October 1998} \\
\hline \multicolumn{4}{|c|}{ Project Title/Work Order } & \multicolumn{2}{|c|}{ EDT No. 620818} \\
\hline \multicolumn{4}{|c|}{$\begin{array}{l}\text { Data Quality Objectives for Sampling of Sludge from the } K \text { West } \\
\text { and K East Basin Floor and From 0ther Basin Areas/HNF-2033, } \\
\text { Rev. } 0\end{array}$} & \multicolumn{2}{|l|}{ ECN No. } \\
\hline \multicolumn{2}{|c|}{ Name } & $\begin{array}{l}\text { Text } \\
\text { With All } \\
\text { Attach. }\end{array}$ & Text Only & $\begin{array}{l}\text { Attach./ } \\
\text { Appendix } \\
\text { Only }\end{array}$ & $\begin{array}{c}\text { EDT/ECN } \\
\text { Only }\end{array}$ \\
\hline
\end{tabular}

Numatec Hanford Corporation
D. B. Bechtoid
D. A. Dodd
T6-07
T6-50
H7-20
$\mathrm{H} 7-20$
T. A. Flament
S4-45
C. A. Petersen
$\mathrm{H} 7-20$

$$
\begin{aligned}
& x \\
& x \\
& x \\
& x \\
& x \\
& x
\end{aligned}
$$

Pacific Northwest National Laboratory
P. R. Bredt
C. H. Delegard
G. R. Golcar
A. J. Schmidt
K. L. Silvers
J. M. Tingey

$\begin{array}{ll}\text { P7-25 } & X \\ \text { P7-25 } & X \\ \text { K6-24 } & X \\ \text { K2-12 } & X \\ \text { K9-08 } & X \\ \text { P7-25 } & X\end{array}$

U.S. Department of Energy, Richland Operations Office

J. Shuen

DOE/RL Reading Room
S7-41

$\mathrm{H} 2-53$ $x$ 